\title{
REVISED PALEOGEOGRAPHY OF THE DINOSAUR BEARING MAASTRICHTIAN LAMETA FORMATION, CENTRAL AND WESTERN INDIA: IN THE PERSPECTIVE OF NEWLY IDENTIFIED SALBARDI-BELKHER INLAND BASIN
}

\section{RUPESH S. MANKAR ${ }^{1 *}$ AND ASHOK K. SRIVASTAVA ${ }^{2}$}

1 Arts, Science and Commerce College, Chikhaldara, Amravati, Department of Geology, Maharashtra, India 2 Sant Gadge Baba Amravati University, Amravati, Department of Geology, Maharashtra, India

*Corresponding Author, rupeshmankar2008@rediffmail.com

\section{Received on 9 September 2018}

Received in revised form on 4 January 2019

Accepted on 6 January 2019

Editor: Rodrigo Tomassini, Universidad Nacional del Sur, Buenos Aires, Argentina

\section{Abstract}

The Lameta sediments covering the geographical area of about $5,000 \mathrm{~km}^{2}$ in central and western India are well documented for their sedimentological and paleobiologic aspects in last four decades. Occurrences of dinosaurian remains including bones, coprolites, eggs, eggshells and nests in mainly arenaceous lithounits of the successions exposed at various localities have been widely used as a significant tool for precise reconstructions of paleogeographic and paleoenvironmental set-up during the Maastrichtian period. Based on sedimentological and paleobiologic aspects, earlier it was considered that the Lameta sedimentation took place in only five inland basins viz., i) Nand-Dongargaon, ii) Jabalpur, iii) Sagar (Saugor), iv) Ambikapur-Amarkantak and v) Balasinor-Jhabua. Recently, a sixth inland basin has been added by Mankar and Srivastava, Salbardi-Belkher, which has been highlighted because of its bearing on the overall picture of Lameta sediments deposition, dinosaur inhabitation and its paleogeographic limit. The categorizations of these inland

\section{Introduction}

The Lameta sediments were widely reported from central and western parts of the India exposed at district Jabalpur, Madhya Pradesh, Nagpur and Chandrapur districts of Maharashtra (Tandon et al., 1990, 1995; Mohabey et al., 1993; Mohabey, 1996 a; Khosla et al., 2005; Mohabey and Samant, 2005, 2009, 2013; Fernández and Khosla, 2015) and Kheda districts of Gujarat (Mohabey, 1984; Srivastava et al., 1986; Sahni, 1993; Khosla and Sahni, 1995, 2003; Mohabey and Samant, 2013; Khosla and Verma, 2015). Scattered occurrences were also reported from Sagar and Amrakanthak districts of Madhya Pradesh (Mohabey, 1996 a) and adjoining areas of Amravati districts of Maharashtra
Citation:

Mankar, R.S. and Srivastava, A.K., 2019. Revised paleogeography of the dinosaur bearing Maastrichtian Lameta Formation, central and western India: in the perspective of newly identified Salbardi-Belkher Inland Basin. Journal of Sedimentary Environments, 4 (1): 53-71.

basins had been done on the basis of detailed study including correlations of litho- and biofacies in respective areas. The presently explored Salbardi-Belkher area, owing several localities of Lameta sediments having preservations of skeletal remains, nest and eggs of dinosaurs, is altogether a separate geographical set-up, besides the earlier reported five inland basins. Taking into consideration of the lithofacies architecture of various successions of the new basin, it has been interpreted that the deposition of the Lameta sediments during the Maastrichtian period was contemporaneously taking place in this additional inland basin, situated in the west of Nand-Dongargaon inland basin. This addition of new inland basin of fluvial regime including evidences of dinosaur remains depicts a revised paleogeographic set-up of Lameta sedimentation in central and western India.

Keywords: Paleogeography. Maastrichtian. Dinosaur. Inland Basin. Fluvial-Lacustrine. Paleoenvironment.

and Betul, Madhya Pradesh (Srivastava and Mankar, 2012 a, b, 2013, 2015 a, b; Mankar and Srivastava, 2015) (Fig. 1). These successions were mostly considered to be the deposits of fluvial-lacustrine set-up; however, the column exposed at the type area of Jabalpur bears a debate about its environment of deposition i.e., coastal complex shallow marine vs. fluvial-lacustrine. The former option has been proposed on the basis of the occurrence of algal structures and glauconite minerals in green colored sandstone bed of the succession (Chanda, 1963 a, b, 1965, 1967; Singh, 1981; Singh and Srivastava, 1981; Chanda and Bhattacharya, 1966); lithological architecture including horizons with extensive development of crab burrows i.e., Thalassinoides (Kumar and Tandon, 1977, 1978, 1979). 


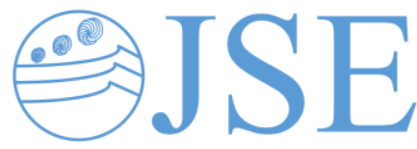

REVIEW PAPER
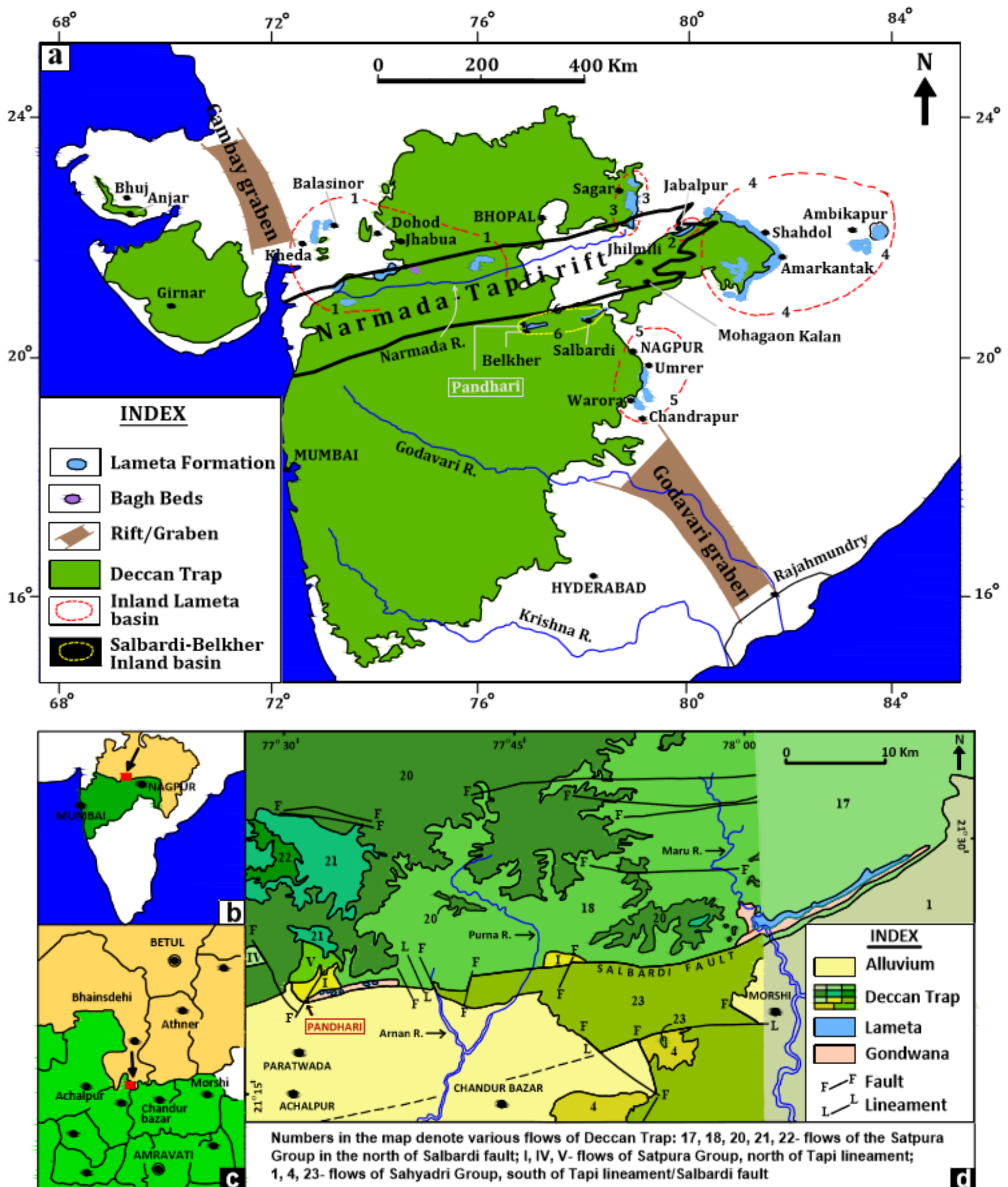

Numbers in the map denote various flows of Deccan Trap: 17, 18, 20, 21, 22- flows of the Satpura Group in the north of Salbardi fault; I, IV, V- flows of Satpura Group, north of Tapi lineament; 1, 4, 23- flows of Sahyadri Group, south of Tapi lineament/Salbardi fault

Fig. 1. Map showing: A) distribution of Lameta sediments in various inland basins viz., i) Nand-Dongargaon, ii) Jabalpur, iii) Sagar, iv) Ambikapur-Amarkantak, v) Balasinor-Jhabua and vi) Salbardi-Belkher and major sea way along the Narmda-Tapi rift (Mohabey, 1996 a; Bajpai, 2009; Keller et al., 2009; Mankar and Srivastava, 2015), B) map showing: study area in a) regional set-up, b) local set-up and c) locations of Bairam, Belkher, Pandhari and Salbardi localities of Lameta (GSI 2001, 2002) (Srivastava and Kandwal, 2016). 


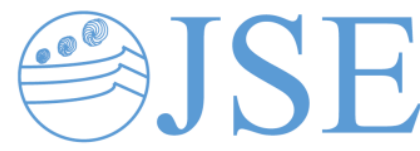

REVIEW PAPER
Recently, Shukla and Srivastava (2008) and Saha et al. (2010) suggested coastal complex setting on the basis of records of lizard eggs and trace fossils of marine affinity. The other group of researchers favoring fluvial-lacustrine environments of deposition for most of the Lameta sediments in India including the succession of type area, advocates on the basis of fossils biota and lithological characteristics as the main tools i.e., non-marine flora and fauna including abundant skeletal remains, eggs, eggs-nests and coprolites of dinosaurs (Mately, 1921; Pascoe, 1964; Mohabey, 1996 a; Srivastava and Mankar, 2013, 2015 b); characteristic lithological association of alluvial plain environment under hot and semi-arid conditions, Jabalpur area (Brookfield and Sahni, 1987); fluvial and pedogenically modified semi-arid, pre-palustrine flat system, Jabalpur area (Tandon et al., 1990); carbonate-chert fluvio-limnic association in Gujarat State (Joshi and Ganapathi, 1990; Mohabey, 1991); facies association including sedimentary petrological characteristic depicting lacustrine set-up, NandDongargaon area, Nagpur (Singh and Tandon, 2004; Mohabey and Samant, 2005); occurrence of pedogenic calcretes formed in sub-aerially exposed area of low gradient alkaline flat alluvial setting, Jabalpur (Tandon et al., 1995, 1998; Tandon and Andrews, 2001); lithological set-up, facies architecture and granulometric analysis of the succession exposed in Salbardi-Belkher inland basin (Srivastava and Mankar, 2010, 2012 a, b, 2015 a; Mankar and Srivastava, 2015; Srivastava and Kandwal, 2016). All these co-eval exposures of different localities exhibit a remarkable similarity in their lithological set-up as well as the faunal contents. Abundant dinosaurian remains e.g. skeletal fragments, eggs, eggs-nests and coprolites from the Lameta successions of various areas belonging to sauropod and theropod families indicate semi-arid climate and fluviallacustrine environments of deposition i.e., Jabalpur inland basin (Tandon et al., 1995; Mohabey, 2001; D'Emic et al., 2009; Carrano et al., 2010), Nand-Dongargaon (Mohabey and Udhoji, 1993), Balasinor-Jhabua (Mohabey, 1983, 1987; Jain and Bandopadhyay, 1997), Salbardi-Belkher (Srivastava and Mankar, 2013, 2015b).

Based on the lithological characteristics and faunal contents, Mohabey (1996 a) identified five separate inland basins of fluvial-lacustrine nature, in which, the Lameta sediments were deposited simultaneously viz., i) NandDongargaon, ii) Jabalpur, iii) Sagar, iv) AmbikapurAmarkantak, and v) Balasinor-Jhabua. The architectures of these inland basins show remarkable similarity; however, differs in lateral correlatability as having basinal control instead of time (Mohabey, 1996 a; Shukla and Srivastava, 2008). Recently, a new inland basin of Lameta sedimentation has been proposed on the basis of limited study viz., Salbardi-Belkher, making a total of six inland basins in central and western India (Mankar and Srivastava, 2015). This basin was established on the basis of new record of 7 8 nearby isolated Lameta exposures, lying in the vicinity of
10-40 km aerial distances, of which, four successions of comparatively larger dimensions are exposed at the localities

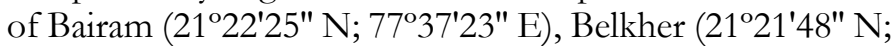
$77^{\circ} 31^{\prime 2} 23^{\prime \prime}$ E), Pandhari $\left(21^{\circ} 22^{\prime} 02^{\prime \prime} \mathrm{N} ; 7^{\circ} 32^{\prime} 54^{\prime \prime}\right.$ E) and Salbardi $\left(21^{\circ} 25^{\prime} 15^{\prime \prime} \mathrm{N}\right.$; $\left.78^{\circ} 00^{\prime} 00^{\prime \prime} \mathrm{E}\right)$ areas, in addition to 3-4 small exposures at nearby places. The successions at two localities viz., Salbardi and Pandhari, have preservations of dinosaur bones and eggs. Recently, certain calcareous algae have also been reported from discontinued thin bed of calcmarl, preserved in the lower part of the succession at Pandhari area (Srivastava et al., 2018). The identification of the Salbardi-Belkher basin is based on the establishments of lithological architectures of various successions exposed at above mentioned localities, reconstruction of depositional environments and the presence of dinosaurian remains.

In the present study, an attempt has been made to discuss the Salbardi-Belkher inland basin in detail and to compare its depositional environment set-up and dinosaurian remains with those of the other five basins aiming to establish a regional picture of paleogeographic set-up in central and western parts of the India during Maastrichtian times.

\section{Geology, age and stratigraphy of the area}

The Lameta successions confined to Salbardi-Belkher inland basin, disconformably overlying along with the Upper Gondwana succession ( $\approx$ the Jabalpur Formation), are exposed in the basaltic country of Deccan Trap as an inlier due to tectonic activity of the Satpura and other allied faults (Fig. 1, Table 1). In the regional set-up, quartz-feldspathic gneiss of the Archaean age forms the basement. The Upper Gondwana succession unconformably overlies the Archaean and is mainly represented by areno-argillaceous sediments having preservation of medium to large scale cross and parallel beddings. This sedimentary succession is disconformably overlain by the Lameta sediments which are areno-argillaceous and calcareous in nature. Deccan trap forms the capping and represented by melanocratic, hard, massive and vesicular to amygdaloidal basalts. The lithological similarities of the Gondwana sediments of Salbardi area with those of the exposures at Bairam and Belkher localities suggest the same age hence, considered being a co-eval lithounit (Srivastava and Mankar, 2008). The age of the Upper Gondwana successions exposed at Bairam and Belkher area is assigned as Upper Jurassic to Early Cretaceous on the basis of gymnosperm and pteridophytic remains (Srivastava et al., 1995, 1999).

\section{Lameta successions of the area}

Despite 3-4 small, scattered patches, the basin shows comparatively good development of the Lameta successions at four places viz., Bairam, Belkher, Pandhari and Salbardi. The successions exposed at all these localities are broadly similar in nature; however, lateral facies variation, pinching and swelling of various lithounits have been noticed. At 
Bairam locality, the column is ca. $39 \mathrm{~m}$ thick and represented mainly by clay-marl, arenaceous and calcareous sediments of almost equal thickness (Fig. 2). Here, the lower $12 \mathrm{~m}$ of the column consists of brownish-yellowish-greenish clays which are occasionally interbedded with thin beds of siliceous limestone and medium to fine grained sandstones. The middle $13 \mathrm{~m}$ of the column is mostly arenaceous, of which, the lower $2 \mathrm{~m}$ succession is grayish brown, medium to coarse grained sandstone, overlain by $9 \mathrm{~m}$ of clay-marl, which contains thin discontinuous beds of siliceous limestone. The overlying $2 \mathrm{~m}$ lithounit is hard and compact, medium to coarse grained bioturbated sandstone. This column shows preservation of abundant arenaceous concretions of 2 to 14 $\mathrm{cm}$ diameters. The upper $14 \mathrm{~m}$ of the column is calcareous, which is easily divisible into nodular limestone and chertified limestone. The nodular limestone contains clasts of chert and Jasper, whereas, the chertified limestone is indurated and shows poor tendency of flat bedding. Chertification is mostly in the form of horizontal discontinued beddings.

The succession outcropping at Belkher area is comparatively well developed and attains the height of about $47 \mathrm{~m}$ (Fig. 2). The arenaceous sediments are comparatively more developed and form the lower $21 \mathrm{~m}$ of the column with occasional occurrences of clay bands. The sandstones are mostly yellowish orange to grayish brown in color, medium to fine grained and show parallel beddings and cross beddings. Preservations of Thalassinoides and other feeding burrows have also been reported from grayish brown sandstone lithounit (Srivastava and Mankar, 2012 a). The middle $12 \mathrm{~m}$ of the column is calc-marl and contains abundant greenish black, subangular to subrounded, hard and compact concretions. The upper calcareous column, consisting of nodular and chertified limestones, having a thickness of about $14 \mathrm{~m}$, is similar to that of the Bairam area.

Tab. 1. Regional stratigraphic set-up of the area.

\begin{tabular}{|c|c|c|}
\hline Age & Stratigraphic units & Rock types \\
\hline Quaternary & & Alluvium and Soil \\
\hline \multicolumn{3}{|c|}{----------------------------------------------------------- Unconformity------------------------------------------------------------ } \\
\hline L. Cretaceous to Eocene & Deccan Trap & $\begin{array}{l}\text { Grayish black, hard and compact, non } \\
\text { porphyritic and porphyritic basalts }\end{array}$ \\
\hline \multicolumn{3}{|c|}{ 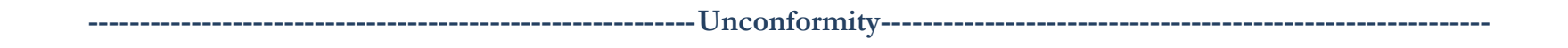 } \\
\hline L. Cretaceous & Lameta & Sandstone, claystone, mudstone and limestone \\
\hline \multicolumn{3}{|c|}{ 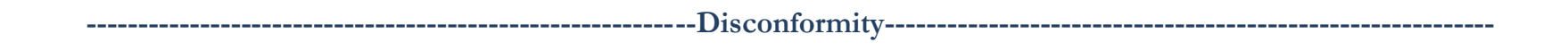 } \\
\hline E. Cretaceous & $\begin{array}{l}\text { Upper Gondwana } \\
\text { ( } \approx \text { Jabalpur Formation })\end{array}$ & $\begin{array}{l}\text { Sandstone, siltstone, conglomerate, claystone } \\
\text { and mudstone Upper Gondwana }\end{array}$ \\
\hline Archaean & & $\begin{array}{l}\text { Quartz-feldspathic gneiss with dolerite } \\
\text { intrusions. }\end{array}$ \\
\hline
\end{tabular}

The succession at Pandhari area (Fig. 2), with a thickness of $\approx 37 \mathrm{~m}$ can be considered as an eastward extension of the Belkher succession, lying at an aerial distance of about 1.5 $\mathrm{km}$; however, differs locally in lithological set-up. Here, argillaceous lithofacies are well developed in the lower $9 \mathrm{~m}$ of the column, represented by greenish gray to yellowish brown clays with irregular sandy concretions and discontinued beds of light to dark gray micritic limestone. The overlying $19 \mathrm{~m}$ of the column is dominantly arenaceous, having shades of pale brown to pale reddish, medium to fine grained, friable to hard sandstones. The upper $5 \mathrm{~m}$ part of this arenaceous column shows preservation of abundant irregular concretions of 10 to $13 \mathrm{~cm}$ diameter, having similar lithology as of the host rock. The top $9 \mathrm{~m}$ of the column is calcareous in nature, represented by brecciated, nodular and chertified limestones.
Salbardi area exhibits $35 \mathrm{~m}$ thick sediment column, of which, the lower $9 \mathrm{~m}$ is dominantly arenaceous and represented by dark brown, thinly bedded, coarse to medium grained sandstone with parallel and cross beddings. Intercalations of clayey beds can also be noticed. The overlying $10 \mathrm{~m}$ column exhibits frequent lithological variation i.e., the lower $2 \mathrm{~m}$ succession is calcareous and shows pedogenic activity represented by cylindrical calcretes. It is overlain by one-meter thick, light green, parallel bedded calcareous sandstone succeeded upward by $2 \mathrm{~m}$ thick light brown micritic calcrete which is overlain by $5 \mathrm{~m}$ thick reddish-brown clayey beds. The upper $16 \mathrm{~m}$ calcareous unit is represented by nodular limestone and chertified limestone or, occasionally by their alternations. The top $4 \mathrm{~m}$ of this calcareous lithounit is represented by intraformational brecciated limestone which is micritic and contains large clasts of nodular and chertified limestones. 

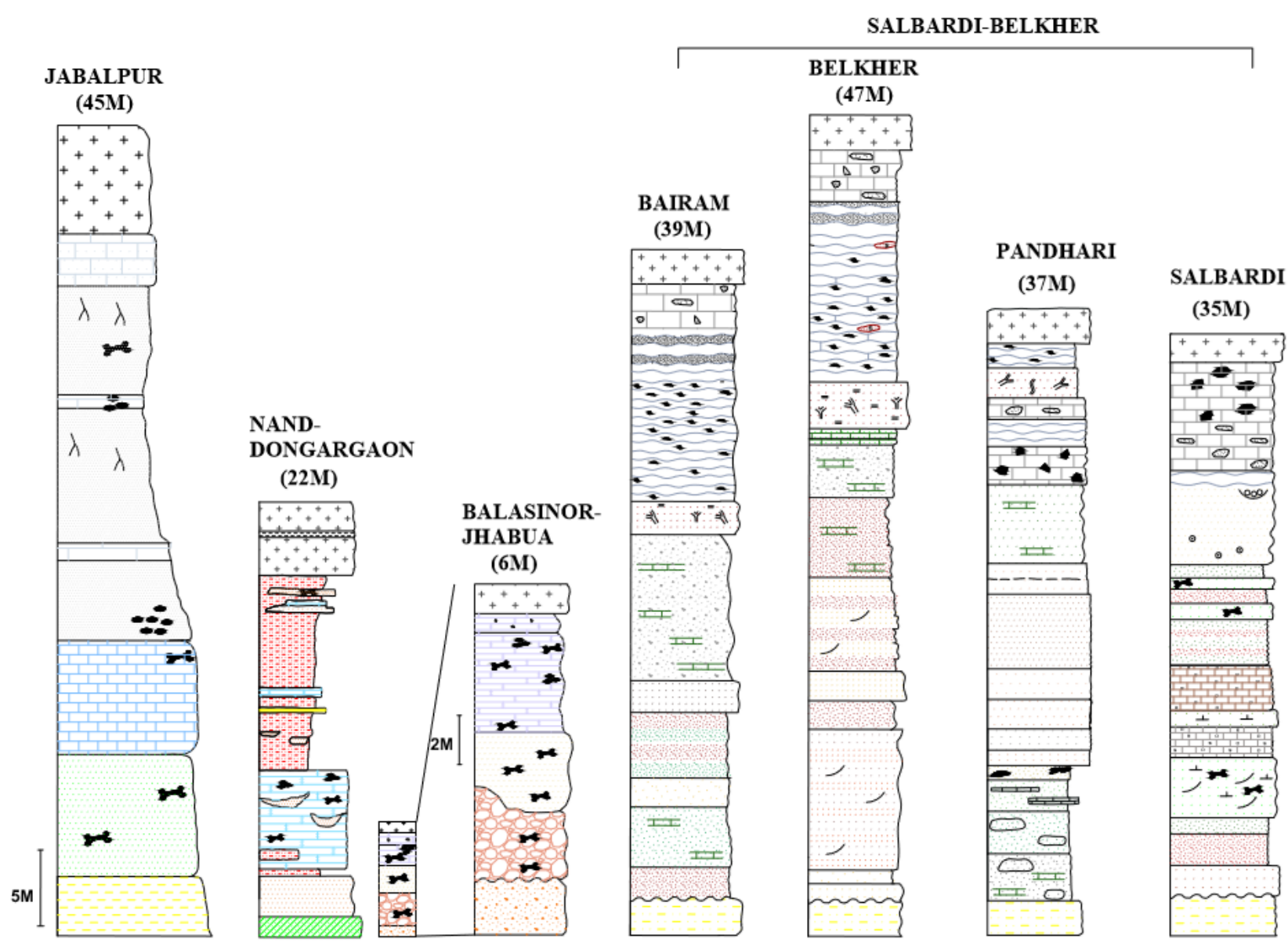

\begin{tabular}{|c|c|}
\hline \\
\hline \multicolumn{2}{|c|}{ SALBARDI-BELKKHER } \\
\hline$\div$ & DECCAN TRAP \\
\hline- & BRECCAATED LIIESTONE \\
\hline 10 & CHERTIFIED LDIESTONE \\
\hline 2 & NODULAR LIMESTONE \\
\hline 느 & BIOTURBATED SANDSTONE \\
\hline & CALY WTTH CONCRETIONS \\
\hline 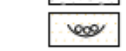 & $\begin{array}{l}\text { CALCRETIZED SANDSTONE WTTH } \\
\text { DINOSAUR NEST }\end{array}$ \\
\hline 罚 & CALCRETE \\
\hline 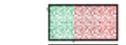 & CLAYS \\
\hline n & SANDSTONE WITH DINOSAUR BONES \\
\hline & GONDWANA \\
\hline \multicolumn{2}{|c|}{ BALASINOR-JHABUA } \\
\hline$=-$ & DINOSAUR NESTSEGGS \\
\hline (n) & DINOSAUR BONES \\
\hline & $\begin{array}{l}\text { CALCRETE / ARENACEOUS LMIESTONE } \\
\text { SANDSTONE }\end{array}$ \\
\hline 88 & CONGLOMERATE \\
\hline & POST-ARAVALI GRANTTE \\
\hline \multicolumn{2}{|c|}{ NAND-DONGARGAON } \\
\hline & MARL \\
\hline & CAL-SILICRETE \\
\hline E: & RED SIITY CLAY \\
\hline & SANDSTONE \\
\hline & PRECAMBRLAN \\
\hline \multicolumn{2}{|c|}{ JABALPUR } \\
\hline & UPPER CALCIFIED LMIISTONE \\
\hline$=$ & MOTTLED NODULAR LDIESTONEEGGS \\
\hline & LOWER LIMESTONE \\
\hline & $\begin{array}{l}\text { GREEN SANDSTONE } \\
\text { JABALPUR CLAY }\end{array}$ \\
\hline
\end{tabular}

Fig. 2. Comparative view of the lithologs showing vertical set-up of Lameta successions at various inland basins in central and western India (Mankar and Srivastava, 2015). 


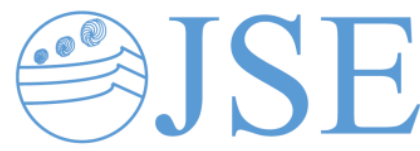

REVIEW PAPER

\section{Dinosaur remains including bones, eggs and coprolites}

Dinosaur remains were collected from the two areas viz., Salbardi and Pandhari. The light green colored sandstone of Salbardi area has abundant fragmentary bones (Fig. 3A-D). A fragment of right ulna belonging to Titanosaurus colberti has been reported by Srivastava and Mankar (2013) (Fig. 3E). In addition, nests and eggs belonging to Megaloolithus oogenus of Megaloolithidae oofamily confirm the area as a suitable site for nesting (Srivastava and Mankar, 2015 b) (Fig. 3F). Pandhari area includes fragmentary bones and rare occurrence of coprolites.

\section{Facies analysis and depositional environments}

Srivastava and Mankar (2010, 2012 b, 2013) have already documented detailed petrography, lithofacies analysis and reconstruction of depositional environments for the successions of Bairam, Belkher and Salbardi areas. In the present paper, a generalized idea about the lithofacies architecture of the succession is being provided. Basically, three lithofacies associations have been identified which are as follows:

\subsection{Arenaceous lithofacies association}

\subsubsection{Massive sandstone lithofacies \\ 5.1.2. Green sandstone lithofacies \\ 5.1.3. Thinly bedded, yellowish orange and grayish brown sandstone lithofacies \\ 5.1.4. Coarse grained sandstone lithofacies \\ 5.1.5. Dark brown bioturbated sandstone lithofacies}

5.2. Argillaceous lithofacies association

5.2.1. Yellowish-brownish-greenish clay-siltstone lithofacies

5.2.2. Light gray silty clay with concretions lithofacies

5.3. Calcareous lithofacies association

\subsubsection{Calcrete lithofacies \\ 5.3.2. Nodular limestone lithofacies \\ 5.3.3. Chertified limestone lithofacies \\ 5.3.4. Intraformational breccia lithofacies}

Table 2 shows the lithofacies architecture of the succession, various lithofacies identified, their characteristic features and depositional environments. Based on the lithological architecture of various successions exposed at three different localities, the depositional environment setup of the basin has been interpreted in detail and a model showing successive developments in fluvial set-up and deposition of corresponding rock types have also been suggested (Srivastava and Mankar, 2015 a) (Fig. 4). The depositional model depicts an overall fluvial-lacustrine setup, in which, temporal variations in depositional setting and climatic conditions have also been observed. The lower part of Lameta succession at Salbardi area, overlying disconformably the Gondwana succession, reflects low energy condition of deposition. The presence of rounded to subrounded pebbles in both stratigraphic units depicts their common source. Hydrodynamic fluctuations that cause changes in the nature and granulometry of the deposit are well represented by the deposition of fine-grained argillaceous sediments and sandstone with cross and parallel beddings. Seasonal variability of hydrodynamics of the river system is marked by the formation of pedogenic calcretes during arid climate, detached lakes and water bodies during low water condition followed by over flooding and highwater condition of the river channel. A calm and quite water environment is interpreted for a short time period represented by bioturbated sandstone indicating high growth of benthonic fauna and complete churning of the sediments by animal community (Srivastava and Mankar, 2015 a).

The upper part of the succession shows a major change allowing the deposition of predominantly carbonate sediments in an alkaline environment. The huge deposition of nodular and chertified limestones indicates a sheet flood environment of deposition. This phase shows termination of Lameta sedimentation. In the Salbardi area, an additional lithounit of intraformational breccia has been recorded which contains clasts of preexisting rocks in micritic matrix showing gravity flow mode of sediment transport.

\section{Lameta Formation of other inland basins}

\subsection{Jabalpur inland basin}

The basin incorporating the Lameta exposures around Jabalpur area includes the localities of Lameta Ghat, Chui Hill and Bara Simla Hill. The first one represents the type area of the Lameta Formation and is well known for various sedimentological and paleobiological studies; however, the other two localities are also well documented. In the type area, five major lithounits have been reported i.e., i) Green sandstone, ii) Lower limestone, iii) Mottled nodular marl, iv) Upper limestone and v) Upper sandstone (Fig. 2, Table 3) (Tandon et al., 1995). The succession exposed at Lameta Ghat is 18-21 m thick and represented by Lower limestone, Mottled nodular marl and Upper limestone (Singh, 1981; Saha et al., 2010). The adjacent area of Bara Simla Hill exhibits all the five major lithounits constituting $34 \mathrm{~m}$ thick column (Singh, 1981; Singh et al., 1983), whereas, at Chui Hill, it was earlier reported to be 39 m thick by Singh (1981) which was further modified by Saha et al. (2010) as $45 \mathrm{~m}$ thick and absence of the Upper sandstone lithounit. Singh (1981) interpreted the successions as the deposits of estuarine channel to shallow marine coastal complex which is mainly based on the occurrence of Green sandstone and trace fossils. The shallow marine environment has been suggested by various researchers taking into consideration the petrology, lithological architecture, algal structures, 


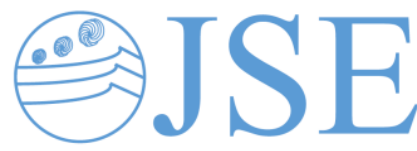

REVIEW PAPER

glauconitic beds and extensive crab burrows including Thalassinoides (Chanda, 1963 a, b, 1965, 1967; Kumar and Tandon, 1977, 1978, 1979; Singh 1981; Singh and Srivastava, 1981).

Shukla and Srivastava (2008) and Saha et al. (2010) reported trace fossils and lizard eggs from the Lameta Formation of Jabalpur area. The trace fossils represented by Arenicolites, Zoophycos, Rhizocorallium and Ophiomorpha depicting typical marine environment are recorded from the Lower limestone, Mottled nodular limestone and Upper limestone. On the basis of ichnofacies, lithofacies architecture and nesting habit of lizards, they interpreted the succession to be a product of intertidal to supratidal channels, marsh, estuary and lagoon subenvironments.

Recently, Srivastava et al. (2015) reexamine the eggshell fragments previously assigned to lizard eggs (Shukla and Srivastava, 2008) and reassigned them to crocodiles and interpreted the paleoenvironment as near shore, lagoonal and supratidal settings of deposition.
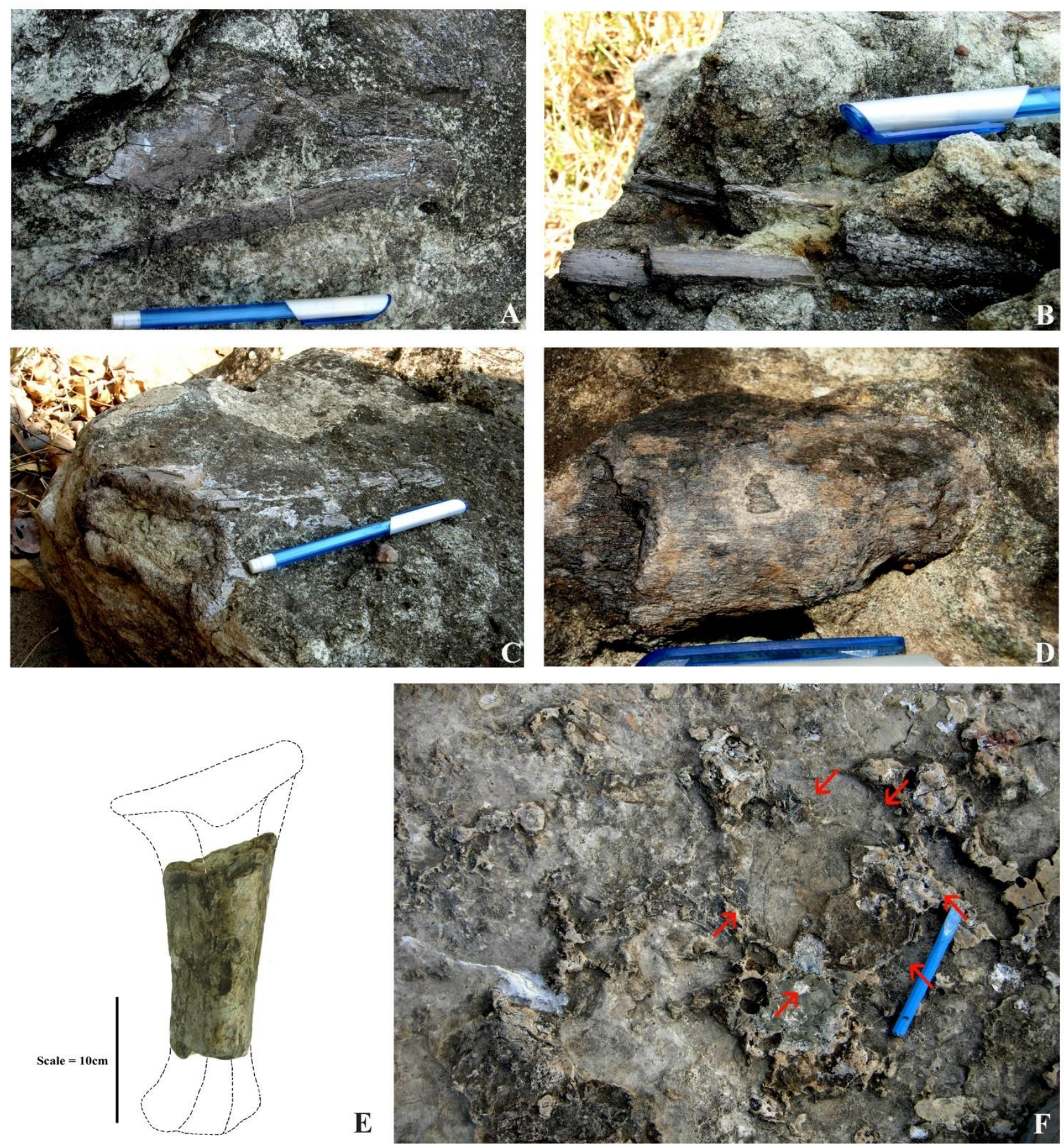

Fig. 3. Photographs showing: A-D) fragments of dinosaur bones, E) reconstruction of right ulna of Titanosaurus colbarti (Srivastava and Mankar, 2013) and F) spherical eggs belonging to Magaloolithus oogenus (Srivastava and Mankar, 2015 b) (all from Salbardi area). 
Tab. 2. Comprehensive view of various lithofacies identified, their characteristic features and respective depositional environments for the Lameta successions of Salbardi-Belkher inland basin (revised after Srivastava and Manakar, 2013).

Facies

association

lithofacies association

Argillaceous lithofacies association
Lihtofacies

\begin{tabular}{ll|} 
Massive & sandstone \\
lithofacies & \\
& \\
& \\
\hline $\begin{array}{l}\text { Green } \\
\text { lithofacies }\end{array}$ & sandstone
\end{tabular}

lithofacies

Thinly bedded, yellow Alternations of yellowish orange and grayish brown orange and grayish brown sandstone lithofacies

Coarse grained Poorly sorted, coarse to medium grained sandstone with sandstone lithofacies

Dark brown, bioturbated sandstone lithofacies

Yellowish-brownish-

Light gray silty clay

with concretions

lithofacies
Characteristics features

Medium grained, hard and compact lithounit with ferruginous cementing material.

Parallel beddings and cross beddings are difficult to record. Lithounit contains pebbles similar as of underlying Gondwana succession, however, less in number. It indicates that the source of sediments for both Gondwana and Lameta formations were the same.

Light to medium green, hard and compact, medium grained lithounit having calcareous cementing material.

Large scales cross beddings and parallel beddings are well preserved which indicate high energy condition of deposition.

Alternations of thin and thick beds of sandstone having large scale and small-scale cross beddings showing fluctuations in the energy condition of the depositional environment. This is also evident by the truncation of structures due to erosional activity. sandstones consisting of medium to coarse grained sediments.

Grayish brown sandstones have ferruginous cementing material whereas, siliceous to ferruginous in yellowish orange sandstones.

Presence of large-scale cross beddings and rounded to subrounded pebbles indicate medium to high energy condition of deposition. abundant granule-size clasts of subangular to angular quartz and feldspar.

It indicates a local variation in the energy condition and the influx of sediments from the nearby area.

Hard and compact, dark brown, medium grained sandstone showing nodular tendency. The unit also shows high bioturbation and lack of mechanically formed sedimentary structures.

Extensive development of crustacean community animals indicates well oxidized environment.

Dominance of clayey argillaceous sediments with thin and poorly laminated silty beds.

Often, the clay with increasing content of silt size sediments grades to siltstone.

Occurrence of abundant calc-marl concretions.

The lithounit shows a quiet shallow aquatic environment allowing the suspension of fine sediments. Contains abundant calc-marl concretions having scattered occurrence in the lithounit.

Depositional

environment

Fluvial

(channel

floor)

Fluvial

(point bar)

Fluvial

(point bar)

Fluvial

Indicates a restricted, comparatively deeper water environment with low energy condition. Presence of angular sand size grains revels the influx of sediments from nearby source. 
Tab. 2. (cont.) - Comprehensive view of various lithofacies identified, their characteristic features and respective depositional environments for the Lameta successions of Salbardi-Belkher inland basin (revised after Srivastava and Manakar, 2013).

Facies association
Lihtofacies

Calcareous lithofacies association
Characteristics features

Calcrete lithofacies
Nodular limestone
lithofacies

Hard and compact, grayish white to light gray calcretised bed with nodular and root calcrete. Both host rock and calcretes include clasts of chert, basalt and green sandstone.

The lithofacies is interpreted to be a product of subaerially exposed, low gradient, alkaline flat environment.

Hard and compact, micritic limestone having subangular to subrounded, medium to coarse, detrital grains and, angular to subangular clasts of chert, jasper, feldspar, quartz etc. up to the dimension of $3 \mathrm{~cm}$. Beds show the nodular tendency.

Lack of sedimentary structures.

On the basis of micrite as the dominant constituent and lack of internal bedding structures, it is interpreted to be a deposit of alkaline flat environment having low energy condition.

Chertified limestone Hard and compact chertified miciritic limestone.

lithofacies

Sedimentary structures are mostly defused, but beds and lenses of chert are present however, the chertification increases in upward direction.

It is interpreted to be the continuation of depositional environment as of the previous lithofacies; however, with reduced alkalinity which may be due to the influx of the siliceous dust produced by the volcanic eruption.

Intraformational Hard and compact, brecciated lithounit having abundant, breccia lithofacies large sized angular to subangular clasts of nodular limestone, chertified limestone and basalt.

Irregular occurrences of angular clasts of preceding lithologies in the micritic groundmass show its deposition by sediment gravity flow. It might be a localized phenomenon.

The environment of deposition for the successions of this basin was also interpreted to be fluvial-lacustrine by many other researchers. This fluvial-lacustrine environment was suggested mainly on the basis of lithological characteristics (Tandon et al., 1995), occurrence of various types of calcretes (Brookfield and Sahni, 1987; Tandon et al., 1990, 1995, 1998; Tandon and Andrews, 2001) and dinosaurian remains (Matley, 1921; Pascoe, 1964; D'Emic et al., 2009).

\subsubsection{Dinosaur remains}

Rich assemblage of dinosaur skeletal remains was reported from the Jabalpur area i.e., caudal vertebrae, tooth and skull of sauropods, theropods and ornithopods (Table 4). Sauropods include Titanosaurus indicus and Antarctosaurus septentrionalis; theropods are represented by Indosuchus (Indosaurus) raptorius, Indosuchus matleyi, Lametasaurus indicus, Composuchus solus, Laevisucbus indicus, Jubbalppuria tenuis, Dryptosauroides (?) grandis, Ornithomimoides mobilis,
Ornithomimoides barasimlensis; and ornithopoda includes Brachypodasaurus gravis (Hislop, 1859; Lydekker, 1877, 1879, 1890; Chatterjee, 1978; Mathur and Pant, 1986; Mohabey, 1987; Vianey-Liaud et al., 1987; Huene and Matley, 1993; Jain and Bandhopadhya, 1997; Loyal et al. 1999) (Table 4). Recently, Wilson et al. (2003) and Wilson and Upchurch (2003) reexamined various species reported from Lametas of India on the basis of valid taxonomic characteristics and assigned valid species names for sauropods and theropods. Accordingly, the valid species of sauropods includes Titanosaurus colbarti (now referred as Isisaurus colberti) and Jainosaurus septentrionalis; whereas, theropods are limited to only Inosuchus raptorius, Indosuchus matleyi and Laevishuchus indicus.

\subsubsection{Nests and Eggs}

Dinosaur nests, eggs and eggshells are well reported from this inland basin. The eggs occur in association with the nest and are well preserved in the form of complete, incomplete 
Tab. 3. Lithological set-ups and depositional environments of the Lameta formations exposed in various inland basins of central and western India (Mankar and Srivastava, 2015).

\section{Jabalpur Basin}

\begin{tabular}{|l|l}
\hline Lithology & 1) Upper sandstone \\
2) Upper limestone \\
3) Mottled nodular marl \\
4) Lower limestone \\
5) Green sandstone
\end{tabular}

(Singh, 1981; Tandon et al., 1990,1995)

\begin{tabular}{|c|c|c|c|}
\hline & Marine & $\begin{array}{l}\text { 1) Intertidal } \\
\text { 2) Intertidal } \\
\text { 3) Tidal flat } \\
\text { 4) Tidal flat } \\
\text { 5) Estuarine } \\
\text { (Singh, 1981) }\end{array}$ & $\begin{array}{l}\text { 1) Intertidal-supratidal } \\
\text { 2) Intertidal channels on the } \\
\text { marshes } \\
\text { 3) Marsh } \\
\text { 4) Lagoon } \\
\text { 5) Estuary } \\
\text { (Saha et al., 2010; Srivastava et al., } \\
\quad 2015 \text { ) }\end{array}$ \\
\hline
\end{tabular}

environment

$\left.\begin{array}{l|l}\begin{array}{l}\text { Non- } \\ \text { marine }\end{array} & \begin{array}{l}\text { 2) Sheet flood } \\ \text { pedogenically } \\ \text { modified } \\ \text { 3) Palustrine flat } \\ \text { 4) Braided stream }\end{array}\end{array}\right\} \begin{aligned} & \text { Fluvial under semi-arid, } \\ & \text { pedogenically modified and } \\ & \text { flat-palustrine system } \\ & \text { (Tandon et al., 1990, 1995) }\end{aligned}$

Nand-Dongargaon Basin

1) Red green silty clays associated with sandstone

2) Channel related sandstone with calcretised in upper part

3) Yellow laminated clays and interbedded with limestone, marlite and septarian concretion bands

4) Calcrete

5) Gray nodular marls

(Mohabey,1996 a, b; Mohabey and Samant, 2005)
Balasinor-Jhabua Basin

1) Arenaceous limestone

2) Calcareous sandstone

3) Grits

4) Conglomerate

(Sarkar et al., 1991; Singh and Tandon, 2004)

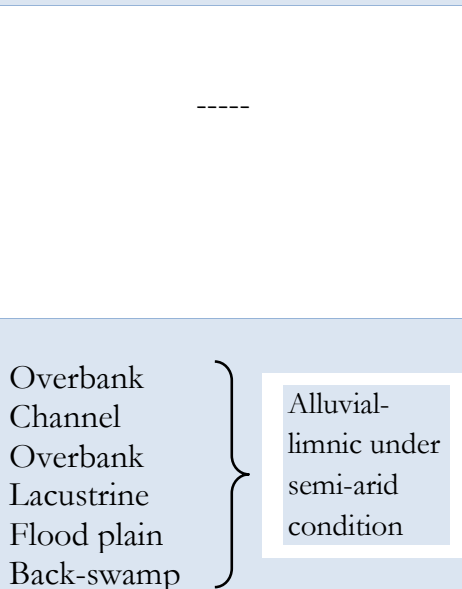

Mohabey, 1996a,b; Mohabey and Samant, 2005)

1) Palustrine environment

2) Fluvial or mostly

lacustrine environment

(Sarkar et al., 1991; Singh

and Tandon, 2004)

and Tandon, 2004$)$
Salbardi-Belkher Basin

1) Intraformational brecciated limestone

2) Chertified limestone

3) Nodular limestone

4) Clay-marl with concretions

5) Yellowish-greenish-reddish claymarl

6) Bioturbated sandstone

7) Grayish yellowish-brownish sandstone

8) Green sandstone

(Srivastava and Mankar, 2010, 2012b; 2013a)

1) Gravity flow

2) Flood plain

3) Flood plain

4) Pedogenic

5) Lacustrine

6) Fluvial

Flvial-

7) Point bar

lacustrine

under semi-

8) Channel floor

arid

(Srivastava and Mankar, 2010, 2012b; 2013a) 
Tab. 4. Bones and eggs of dinosaurs reported from various inland basins of Lameta sedimentation in central and western India.

\begin{tabular}{|c|c|c|c|c|c|}
\hline & \multicolumn{2}{|l|}{ Bones } & \multicolumn{3}{|c|}{ Nests/Eggs } \\
\hline Order & Earlier identified species & New defined species & Oogenus & Earlier identified oospecies & New defined oospecies \\
\hline \multicolumn{6}{|c|}{ Balasinor-Jhabua Basin } \\
\hline Sauropoda & $\begin{array}{l}\text { 1. Antarctosaurus septentrionalis } \\
\text { (Mathur and Pant, 1986) } \\
\text { 2. Titanosaurus rabioliensis (Mathur } \\
\text { and Srivastava, 1987) }\end{array}$ & $\begin{array}{l}\text { Jainosaurus septentrionalis } \\
\text { (Wilson et al., 2003) }\end{array}$ & Megaloolithus & $\begin{array}{l}\text { 1. M. rabioliensis (=cylindricus), } \\
\text { 2. M. phensaniesis, } \\
\text { 3. M. khempurensis (=megadermu), } \\
\text { 4. M. kachchhensis, } \\
\text { 5. M. dhoridungriensis, } \\
\text { 6. M. megadermus } \\
\text { 7. M. balasinorensis (junior synonym of baghensis), } \\
\text { 8. Phensaniensis (junior synonym of mohabeyi), } \\
\text { 9. Problematica (?) } \\
\text { (Mohabey, 1996b; Khosla and Sahni, 1995; } \\
\text { Vianey-Liaud et al., 2003) }\end{array}$ & $\begin{array}{l}\text { 1. M. cylindricus, } \\
\text { 2. M. jabalpurensis } \\
\text { 3. M. megadermus } \\
\text { 4. Fusioolithus baghensis } \\
\text { (Fernández and Khosla, 2015) }\end{array}$ \\
\hline Theropods & $\begin{array}{l}\text { 1. Rajasaurus narmadensis (Wilson et } \\
\text { al., 2003) } \\
\text { 2. Rabiolisaurus gujaratensis }\end{array}$ & $\begin{array}{l}\text { Rajasaurus narmadensis (Wilson } \\
\quad \text { et al., 2003) }\end{array}$ & Ellipsoolithus & -- & -- \\
\hline Sauropods & $\begin{array}{l}\text { 1. Titanosaurus indicus } \\
\text { (Lydekker,1877) } \\
\text { 2. Antarctosaurus septentrionalis } \\
\text { (Huene and Matley, 1993) }\end{array}$ & $\begin{array}{l}\text { 1. Titanosaurus colberti (Isisaurus } \\
\text { colberti) (Wilson and } \\
\text { Upchurch, 2003) } \\
\text { 2. Jainosaurus septentrionalis } \\
\text { (Hunt et al., 1994) }\end{array}$ & Megaloolithus8 & $\begin{array}{l}\text { 1. M. dhoridungriensi, } \\
\text { 2. M. cylindricus, } \\
\text { 3. M. jabalpurensis, } \\
\text { 4. M. matleyi (Junior synonym of jabalpurensis) } \\
\text { 5. M. phensaniensis (Junior synonym of matleyi) } \\
\text { 6. M. mobabeyi, } \\
\text { 7. M. baghensis, } \\
\text { 8. M. dholiyaensis, } \\
\text { 9. M. padiyalensis (Junior synonym of Mobabeyi), } \\
\text { 10. M. dhoridungriensis } \\
\text { (Mohabey, 1996b; Khosla and Sahni, 1995; } \\
\text { Vianey-Liaud et al., 2003) }\end{array}$ & $\begin{array}{l}\text { 1. M. cylindricus, } \\
\text { 2. M. jabalpurensis } \\
\text { 3. M. megadermus } \\
\text { 4. F. baghensis } \\
\text { (Fernández and Khosla, 2015) }\end{array}$ \\
\hline
\end{tabular}


Tab. 4. (cont.) Bones and eggs of dinosaurs reported from various inland basins of Lameta sedimentation in central and western India.

\begin{tabular}{|c|c|c|c|c|c|}
\hline \multicolumn{3}{|c|}{ Bones } & \multicolumn{3}{|c|}{ Nests/Eggs } \\
\hline Order & Earlier identified species & New defined species & Oogenus & Earlier identified oospecies & New defined oospecies \\
\hline \multicolumn{6}{|c|}{ Jabalpur Basin (cont.) } \\
\hline Theropods & $\begin{array}{l}\text { 1. Indosuchus raptorius (Huene and Matley, 1993) } \\
\text { 2. Indosuchus matleyi (Huene and Matley, 1993) } \\
\text { 3. Lametasaurus indicus (Matley, 1924) } \\
\text { 4. Composuchus solus (Huene and Matley, 1993) } \\
\text { 5. Laevisuchus indicus (Huene and Matley, 1993) } \\
\text { 6. Jubbalppuria tenuis (Huene and Matley, 1993) } \\
\text { 7. Dryptosauroides (?)grandis (Huene and Matley, } \\
\text { 1993) } \\
\text { 8. Ornithomimoides mobilis (Huene and Matley, 1993) } \\
\text { 9. Ornithomimoides barasimlensis (Huene and Matley, } \\
\text { 1993) } \\
\text { 10. Ornithogoniosaurus Metleyi (Das-Gupta, 1930) } \\
\text { 11. Coeluroides largus (Huene and Matley, 1993) } \\
\text { 12. Brachypodosaurus gravis (Huene and Matley, 1993) }\end{array}$ & $\begin{array}{l}\text { 1. Indosuchus raptorius (Huene and } \\
\text { Matley, 1993) } \\
\text { 2. Indosuchus matleyi (Huene and } \\
\text { Matley, 1993) } \\
\text { 3.Laevishuchus indicus (Huene and } \\
\text { Matley, 1993) }\end{array}$ & Ellipsoolithus & $\begin{array}{l}\text { E. khedaensis (Mohabey, } \\
\text { 1996b) }\end{array}$ & $\begin{array}{l}\text { E. khedaensis (Mohabey, } \\
\text { 1996b) }\end{array}$ \\
\hline \multicolumn{6}{|c|}{ Nand-Dongargaon Basin } \\
\hline Sauropods & $\begin{array}{l}\text { 1. Titanosaurus indicus (Lydekker,1877) } \\
\text { 2. Titanosaurus blandfordi (Lydekker,1879) } \\
\text { 3. Titanosaurus colberti (Jain and Bandyopadhyay, } \\
\text { 1997) } \\
\text { 4. Laplatasurus madagascariensis (Huene and Matley, } \\
\text { 1933) }\end{array}$ & $\begin{array}{l}\text { Titanosaurus colberti (Isisaurus } \\
\text { colberti) (Wilson and Upchurch, } \\
\text { 2003) }\end{array}$ & Megaloolithus & $\begin{array}{l}\text { 1. M. matleyi } \\
\text { 2. M. megadermus } \\
\text { (Mohabey, 1996b) }\end{array}$ & $\begin{array}{l}\text { 1. M. megadermus } \\
\text { 2. M. jabalpurensis } \\
\text { (Fernández and Khosla, 2015) }\end{array}$ \\
\hline Theropods & ---- & ---- & Ellipsoolithus & -- & -- \\
\hline \multicolumn{6}{|c|}{ Salbardi-Belkher Basin } \\
\hline Sauropods & -- & $\begin{array}{l}\text { Titanosaurus colberti (Isisaurus } \\
\text { colberti) (Wilson and Upchurch, } \\
\text { 2003) }\end{array}$ & Megaloolithus & -- & $\begin{array}{l}\text { Megaloolithus (oogenus) } \\
\text { (Srivastava and Mankar, } \\
\text { 2015b) }\end{array}$ \\
\hline
\end{tabular}


and fragments of Megaloolithus dhoridungriensis, Megaloolithus cylindricus, Megaloolithus jabalpurensis, Megaloolithus matleyi (junior synonym of jabalpurensis), Megaloolithus phensaniensis (junior synonym of matleyi), Megaloolithus mohabeyi, Megaloolithus baghensis, Megaloolithus dholiyaensis, Megaloolithus padiyalensis (junior synonym of mohabeyi), and $M$. dhoridungriensis of the Megaloolithidae oofamily, and Elipsoolithus khedaensis of the Elipsoolithidae oofamily (Mohabey, 1983, 1990, 1996b, 1998, 2000, 2001, 2005;
Brookfield and Sahini, 1987; Joshi, 1995; Khosla and Sahni, 1995; Vianey-Liaud et al., 2003). Recently, Fernández and Khosla (2015) revised dinosaurian eggs of the Megaloolihidae oofamily reported from the Lameta Formation of India and also reexamined all the nine Megaloolithus oospecies reported by Vianey-Liaud et al. (2003) and confined them only in four oospecies viz., $M$. cylindricus, M. jabalpurensis, M. megadermus and Fusioolithus baghensis (Table 4).

A

B

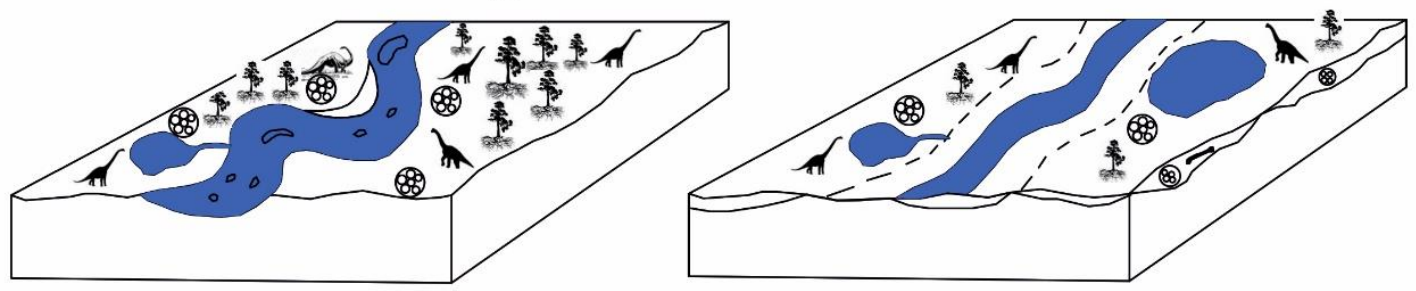

C D
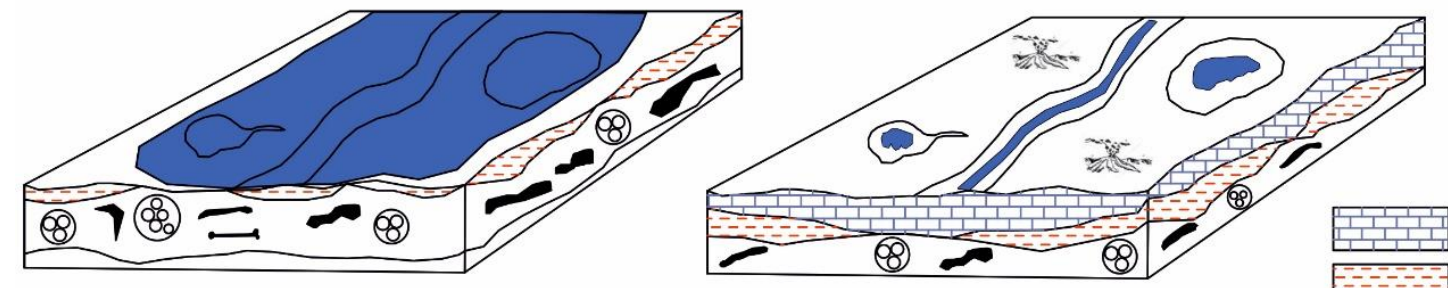

LIMESTONE CLAY

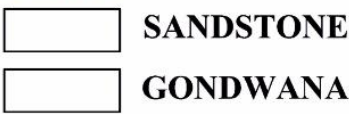

(8) $\approx$ BONES \& EGGS NEST

Fig. 4. Schematic model of the depositional environment for Lameta sediments: A) deposition of arenaceous sediments as channel floor and point-bar deposits over Gondwana sediments, B) development of non-perennial lakes allowing deposition of fine-grained argillaceous sediments, C) large sheet-like deposits have taken place due to overflooding in the entire area including lakes, and D) volcanic activity causing reduction of sites for fluvial-lacustrine deposition. Pedogenic activities might have taken place at any stage but more pronounced during B stage (revised after Srivastava and Mankar, 2015 a).

\subsection{Nand-Dongargaon (N-D) inland basin}

Mohabey (1996 a, b) and Mohabey and Samant (2005) have made detailed investigations of lithological set-up and dinosaurian remains of N-D basin. This basin covers an area about of $700 \mathrm{~km}^{2}$ constituted together by parts of Nagpur and Chandrapur districts of Maharashtra (Mohabey et al., 1993; Mohabey, 1996 a, b; Mohabey and Samant, 2005). Good successions of Lameta Formation are exposed at Pisdura, Dongargaon, Nand, Kotabala of Chandrapur district and Rajulwari, Pahami and Shivapur of Nagpur district (Mohabey and Samant, 2013; Khosla and Verma, 2015). These successions rest unconformably over the Precambrian basement or, the Gondwana rocks. Towards the northern part of basin i.e., in Nand locality, it rests over the Precambrian granite and schist and is marked by $4 \mathrm{~m}$ thick lithocolumn of sandstone, which is conglomeratic at the base and calcretised in upper part (Mohabey,1996 a). In Dongargaon-Pisdura, towards the southern extreme, the
Lameta succession comprises of red and green, nonlaminated silty clay that unconformably rests over the Precambrian granite and schist or, the Kamthi Formation (Mohabey et al., 1993). It is argillaceous in nature forming a column of about $6 \mathrm{~m}$ thickness having interbeddings of sandstone (Fig. 2). Overlying sediments are yellow and cream-colored laminated clays and shales with thin beds of limestones and marlites. The top $4 \mathrm{~m}$ thick column, of which, upper part shows calcretization (Mohabey and Samant, 2005, 2013; Khosla and Verma, 2015). Mohabey (1996 a) based on detailed lithological characteristics, identified four major lithounits viz., i) red and green silty clays associated with sandstones, ii) channel related sandstone (trough and cross-bedded), which are calcretised in the upper part, iii) yellow laminated clays and shales interbedded with limestone, marlite and septarian concretion bands and, iv) gray nodular marls. Based on lithological and sedimentological attributes and faunal content, the above mentioned lithounits are interpreted to be deposited under 
i) channel, ii) overbank, iii) paludal and iv) limnic environments respectively (Mohabey et al., 1993; Mohabey and Udhoji, 1993; Mohabey, 1996 a; Singh and Tandon, 2004). The lacustrine facies is developed in the southern sector of N-D basin which have been further studied in detail revealing sedimentation pattern, climatic control and sediments cyclicity (Mohabey and Samant, 2005).

\subsubsection{Dinosaur remains}

Sauropod remains belonging to T. indicus, T. blandfordi, $T$. colberti, Isisaurus colberti and Laplatasurus madagascariensis were reported from this basin (Lydekker, 1890; Matley, 1921; Chakravarti, 1934, 1935; Berman and Jain, 1982; Jain and Bandhopadhya, 1987; Vianey-Liaud et al., 1987; Jain and Bandhopadhyay, 1997; Carrano et al., 2010). However, according to Wilson and Upchurch (2003) only T. colberti (= Isisaurus colberti) would be a valid genus (Table 4).

\subsubsection{Nests and Eggs}

Megaloolithus matleyi and M. megadermus oospecies of the Megaloolithus oofamily were reported from this basin (Jain and Sahni, 1985; Khosla and Sahni, 1995; Mohabey, 1998, 2000, 2001; Vianey-Liaud et al., 2003); however, according to Fernández and Khosla (2015), only $M$. megadermus oospecies would be a valid species. Chelonian and spherolithidae eggs have also been reported (Mohabey, 1996b, 1998) (Table 4).

\subsection{Balasinor-Jhabua inland basin}

The Lameta Formation, outcropping at Balasinor and Rahioli areas of Kheda and Panchmahal districts of Gujarat were heavily explored for dinosaur bones and eggs. At Balasinor, the 4 to $12 \mathrm{~m}$ thick succession is unconformably developed over the Godhra Granites/Phyllites of Aravalli Supergroup (Fig. 2). The lower 2 to $6 \mathrm{~m}$ thick succession is conglomeratic in nature and shows channel and scour-fill structures with pebbles, quartz veins, cherty quartzite bounded together by calcareous and siliceous cements. This horizon also shows the preservation of abundant dinosaur bones. The bedding characteristic is not distinct; however, locally, the size gradation of the clasts has been reported. This level grades to $2 \mathrm{~m}$ thick, pebbly, poorly sorted sandstone. The sandstone gradually becomes fine grained in upward direction and later grades to limestone which is gray to brown in color and siliceous in nature. The limestone is highly variable in nature i.e., mottled, nodular and brecciated with lithoclasts, peloids and subangular to subrounded detrital quartz. Mohabey (2001) considered it a deposit of palustrine environment which is based on its fine grained, massive and micritic nature, in addition, to the presence of discontinuous cracks and bioturbation. At Rahioli, the sandy calcrete is comparatively well developed and entombs almost complete eggs and nests of dinosaurs (Mohabey, 1984;
Srivastava et al., 1986; Sahni et al., 1994; Loyal et al., 1996, 1999; Fernández and Khosla, 2015; Khosla and Verma, 2015). The depositional environments range mostly from sheet wash to palustrine. The oxygen and carbon isotopic analysis are also suggestive of fluvial or mostly lacustrine environment of deposition, particularly for the egg-bearing horizons (Sarkar et al., 1991; Singh and Tandon, 2004).

\subsubsection{Dinosaur remains}

Bones of the Antarctosaurs septentrionalis and the Rajasaurus narmadensis belonging to the sauropod and theropod respectively (Jain and Bandhopadhya, 1997; Wilson and Upchurh, 2003; Wilson et al., 2003) (Table 4).

\subsubsection{Nests and Eggs}

Megaololithus rabioliensis (=cylindricus), Megaololithus phensaniesis, Megaololithus khempurensis (=megadermus), Megaololithus kachchhensis, M. dhoridungriensis, M. megadermus and $M$. balasinorensis (junior synonym of baghensis), $M$. phensaniensis (junior synonym of mohabeyz), Problematica (?) reported earlier from this basin (Dwivedi et al., 1982; Mohabey, 1983, 1991; Khosla and Sahni, 1995; Loyal et al., 1999; Vianey-Liaud et al., 2003) are now redefined as Megaololithus cylindricus, M. jabalpurensis, M. megadermus and Fusioolithus baghensis by Fernández and Khosla, 2015 (Table 4).

\subsection{Sagar (Saugor) and Amarkantak-Ambikapur inland basins}

Both basins are comparatively less studied and devoid of adequate information in the original paper of Mohabey (1996 a). The Sagar basin, laying in the NW of Jabalpur basin, was categorized on the basis of a north-west elongated patches of Lameta sediments in its geographical areas. This succession consists of gritty sandstone, calcareous clay, chert and mottled limestone having pebbles of jasper and chert. The Amarkantak-Ambikapur basin lying in the uplift part constitutes comparatively very large geographical area; however, lacks sufficient details (Mohabey, 1996 a).

\section{Discussion}

Mohabey (1996 a) proposed five inland basins viz., i) Nand-Dongargaon, ii) Jabalpur, iii) Sagar, iv) AmbikapurAmarkantak and v) Balasinor-Jhabua, in which, the deposition of the Lameta sediments had taken place. The fluvial-lacustrine sediments of Lameta, exposed in these inland basins, have a remarkable similarity in their architectural set-up (Fig. 2). The authors of the present work have recently explored and studied a few isolated patches of Lameta sediments exposed at Bairam, Belkher, Pandhari and Salbardi areas along with 3-4 minor exposures, covering together a large geographical area in wide spread Deccan 
Trap basaltic country. The successions in these areas are fluvio-lacustrine in nature and preserve evidences of dinosaur, including bones, coprolites, nests and eggs. Based on the comparative study of the lithological set-ups and dinosaurian remains of this basin with those of other five inland basins reported earlier, the present authors have already proposed it as a new inland basin for Lameta sedimentation and named Salbardi-Belkher inland basin (Fig. 1). In this basin, the commencement of Lameta sedimentation, after the termination of Gondwana sedimentation, is well marked, however, the sediment supply during deposition of both the lithounits have a common source. It is a significant outcome as at other places in Central and Western India, the Lameta sediments lie unconformably over the older basement with pronounced unconformity.

On the basis of facies analysis, it is interpreted that the sedimentation in the new basin took place in a big riverine plain including lakes which was periodically recharged by the river causing shallowing and deepening of the depositional site in entire course of Lameta sediments deposition. This phenomenon occurred repeatedly during the sedimentation, as the column in the lower part is dominantly represented by bedded units of arenaceous and argillaceous facies depicting the change in energy condition of the depositional environment and also the periodic influx of the sediments having high variation in grain size. During the later stage, the basin was mostly shallow and alkaline in nature represented by dominance of calcareous sediments. In the initial phase, the basin was probably shallow in the eastern part and deep in the west, which is evident by the difference in the nature of sediments in both the geographical extremities. The succession, west of Salbardi area, is noticed to be of arenaceous nature in the lower part that also contains calcrete horizons revealing the shallow nature of the depositional site as compared to the dominance of argillaceous sediments at Belkher and further Pandhari in the extreme west showing comparatively deeper condition.

Comparing it with the other five inland basins as proposed by Mohabey (1996 a), Mankar and Srivastava (2015) infer that the Salbardi-Belkher inland basin was almost similar in size as of Jabalpur; however, elongated in east-west directions. Like others, in this basin also, the deposition of the sediments has a basinal control; however, the thickness of the column is comparatively larger. The dinosaur bones and eggs-bearing horizons are also correlated with similar horizons of various localities of other basins viz., Raholi, Jabalpur and Nand-Dongargaon, that also represent similar deposition environment set-up i.e., channel to point bar subenvironment under sub arid climatic condition.

Taking the newly identified Salbardi-Belkher basin (Mankar and Srivastava, 2015) into consideration, the palaeogeographic set-up during Lameta sedimentation is now been revised with extended geographical limit. The climatic condition in the newly identified basin area was also favorable for survival of dinosaurs and laying their eggs as of Jabalpur, N-D and Balasinor-Jhabua basins hence, the same condition is now extrapolated in the west of adjacent N-D basin.

\section{Conclusion}

In view of the studies carried out for lithological set-up and dinosaurian remains of newly identified SalbardiBelkher fluvial inland basin, and its comparison with earlier established five co-eval depositional basins, the following conclusions have been drawn for the Lameta Formation:

1. The fluvio-lacustrine Lameta sediments exposed in central and western India, earlier considered to be deposited in only five inland basins viz., i) NandDongargaon, ii) Jabalpur, iii) Sagar (Saugor), iv) Ambikapur-Amarkantak and v) Balasinor-Jhabua are now added with an additional basin viz., Salbardi-Belkher making a total of six basins of deposition.

2. The newly identified Salbardi-Belkher inland basin lies in western side of Nand-Dongargaon basin and preserves well developed fluvio-lacustrine Lameta successions exposed at Bairam, Belkher, Pandhari and Salbardi areas besides 3-4 small exposures. Skeletal remains, coprolites, eggs, eggs-nests of dinosaurs are also preserved.

3. A comparative study of the lithological set-ups of earlier known five inland basins of Lameta sediments with those of Salbardi-Belkher basin exhibits similar depositional set-up; however, in the newly established basin, an additional lithounit of gravity flow represented by intraformational brecciated limestone has also been identified at the top.

4. Similarly, the overall comparison of dinosaurian remains show that the Titanosaurus colberti (= Isisaurus colberti), species of sauropod, reported form N-D and BalasinorJhabua basin, also existed in Salbard-Belkher basin. The eggs and nests of Megaloolithus reported from the Salbardi-Belkher basin is also comparable with BalasinorJhabua, Jabalpur and N-D basins at oogenus level.

5. Though, the Salbardi-Belkher basins is very close to N$\mathrm{D}$ basin having almost similar fluvio-lacustrine depositional set-up but, differs remarkably in their lithological set-ups and sub-environments of deposition showing different basinal set-ups in both basins.

6. The inclusion of new inland basin with separate geographical identity reflects a revised paleogeographic set-up having a westward extended limit of Lameta sedimentation and dinosaur inhabitation as compared to the paleogeographic limits proposed earlier on the basis of only five inland basins. 


\section{Acknowledgment}

Financial support in the form of a Major Research Project (F. 40/295/2011; SR) provided by UGC, New Delhi to one of the author (AKS) is thankfully acknowledged. The author (RSM) availed Senior Research Fellowship (F09/855 (0003)/2012) awarded by CSIR, New Delhi.

\section{References}

Bajpai, S., 2009. Biotic perspective of the Deccan volcanism and India-Asia collision: Recent advances. In: Current Trends in Science, Platinum Jubilee Special Publication, Indian Academy of Sciences 505-516.

Berman, D.S., Jain, S.L., 1982. The brain-case of a small sauropod dinosaur (Reptilia: Saurischia) from the upper Cretaceous Lameta Group, Central India with review of Lameta Group localities. Annals of Carnegic Museum 51, 421-420.

Brookfield, H.E. Sahni, A., 1987. Palaeoenvironments of Lameta Beds (Late Cretaceous) at Jabalpur, Madhya Pradesh, India: soil and biotas of a semi-arid alluvial plain. Cretaceous Research 8, 1-14.

Carrano, M.T., Wilson, J.A., Barrett, P.M., 2010. The history of dinosaur collecting in Central India, 1828-1947. Geological Society of London, Special Publication 343, 161-173.

Chakravarti, D.K., 1935. Is Lametasaurus indicus an armoured dinosaur? The American Journal of Science, 5 (30),138-141.

Chakravarti, D.K., 1934. On a stegosaurian humerus from the Lameta Beds of Jubbalpure. Quarterly Journal of the Geological, Mining and Metallurgical Society of India, 5, 75-79.

Chanda, S.K., 1967. Petrogenesis of the calcareous constituents of the Lameta Group around Jabalpur, M. P., India. Journal of Sedimentary Research 37 (2), 425-437. https://doi.org/10.1306/74D716E5-2B21-11D78648000102C1865D

Chanda, S.K., Bhattacharya, A., 1966. A re-evaluation of the stratigraphy of the Lameta-Jabalpur contact around Jabalpur, M. P. Journal of the Geological Society of India 7, 91-99.

Chanda, S.K., 1965. Further notes on the origin of Lameta Beds, Jabalpur, M. P. Science and Culture 31, 633-634.

Chanda, S.K., 1963 a. Cementation and diagenesis of the Lameta Beds, Lametaghat, India. Journal of Sedimentary Research 33 (3), 728-738. https:// doi.org/10.1306/74D70F10-2B21 11D7-8648000102C1865D

Chanda, S.K., 1963 b, Petrology and origin of Lameta sandstone, Lameta Ghat, Jabalpur, M. P., India. Proceedings of the National Institute of Sciences of India 29 (A), 578587.

Chatterjee, S., 1978. Indosuchusa and Indosaurus, Cretaceous carnosaurs from India. Journal of Palaeontology 52 (3), 570-580.

D'Emic, M.D., Wilson, J.A., Chatterjee, S., 2009. The titanosaur (Dinosauria: Sauropoda) osteoderm record: review and first definitive specimen from India. Journal of Vertebrate Paleontology 29 (1), 165-177. https://doi.org/ 10.1671/039.029.0131

Dwivedi, G.N., Mohabey, D.M., Bandyopadyay, S., 1982. On the discovery of vertebrate fossils from Infratrappean

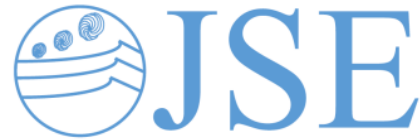

Rt Trends in Geology Lameta beds, Kheda District, Gujrat. Current Trends in Geology 7, 79-87.

Fernández, M.S., Khosla, A., 2015. Parataxonomic review of the Upper Cretaceous dinosaur eggshells belonging to the oofamily Megaloolithidae from India and Argentina. Historical Biology 27 (2), 158-180. https://doi.org/ 10.1080/08912963.2013.871718

GSI, 2001. District Resource Map-Amravati district, Maharashtra. Government of India publication.

GSI, 2002. District Resource Map-Betul district, Madhya Pradesh. Government of India publication.

Hislop, S., 1859. On the Tertiary deposits associated with the Trap rocks in the Windies. Quaternary Journal of the Geological Society of India 16, 154-185.

Huene, F.V., Matley, C.A., 1933. The Cretaceous Saurischia and Ornithischia of the central provinces of India. Memories of Geological Survey of India. Palaeontologia Indica 21(1), 1-72.

Hunt, A.P., Lockley, M.G., Lucas, S.G., Meyer, C.A., 1994. The global sauropod fossil record. Gaia 10, 261-279.

Jain, S.L., Bandopadyay, S., 1997. New titanosaurid (Dinosauria: Sauropopda) from the Late Cretaceous of Central India. Journal of Vertebrate Paleontology 17(1),114-136.

Jain, S.L., Sahni, A., 1985. Dinosaur eggshell fragments from the Lameta Formation at Pisdura, Chandrapur District, Maharashtra. Geoscience Journal 2, 211-220.

Joshi, A.V., 1995. New occurrence of dinosaur eggs from Lameta Formation (Maastrichtian) near Bagh, Madhya Pradesh. Journal of the Geological Society of India 46, 439443.

Joshi, A.V., Ganapathi, S., 1990. Carbonate-chert association in lacustrine environment of Lameta formation of Gujarat state, India. 13 ${ }^{\text {th }}$ International Sedimentological Conference, Abstract, Nottingham, p. 13.

Keller, G., Adatte, T., Bajpai, S., Mohabey, D.M., Widdowson, M., Khosla, A., Sharma, R., Khosla, S.C., Gertsch, B., Fleitmann, D., Sahni, A., 2009. K-T transition in Deccan traps and intertrappean beds in central India mark major marine seaway across India. Earth Planetary Science Letters 282, 10-23.

Khosla, A., Verma, O., 2015. Paleobiota from the Deccan volcano-sedimentary sequences of India: paleoenvironments, age and paleobiogeographic implications. Historical Biology 27 (7), 898-914. https://doi.org/10.1080/08912963.2014.912646

Khosla, S.C., Nagori, M.L., Mohabey, D. M., 2005. Effect of Deccan volcanism on non-marine Late Cretaceous ostracode fauna: a case study from Lameta Formation of Dongargaon area (Nand-Dongargaon basin), Chandrapur District, Maharashtra. In: Mohabey, D.M. (Ed.), Indian Non-Marine Late Cretaceous: Advances and Challenges. Gondwana Geological Magazine, Special Volume, 8, 133146.

Khosla, A., Sahni, A., 2003. Biodiversity during the Deccan volcanic eruptive episode. Journal of Asian Earth Sciences 21 (8), 895-908. https://doi.org/10.1016/S1367-9120(02)00092-5

Khosla, A., Sahni, A., 1995. Parataxonomic classification of Late Cretaceous dinosaur eggshell from India. Journal of the Palaeontological Society of India 40, 87-102. 
Kumar, S., Tandon, K.K., 1979. Trace fossils and environment of deposition of the sedimentary succession of Jabalpur, M. P. Journal of the Geological Society of India 20, 103-106.

Kumar, S., Tandon, K.K., 1978. Thalassinoides in the Mottled Nodular Beds, Jabalpur area, M. P. Current Science 47(2), 52-53.

Kumar, S., Tandon, K.K., 1977. A note on bioturbation in the Lameta beds, Jabalpur area, M.P. Geophytology 7 (2), 135 138.

Loyal, R.S., Mohabey, D.M., Khosla, A., Sahani, A., 1999. Status and paleobiology of the Late Cretaceous Indian theroods with description of new theropod eggshells oogenus Ellipsoolithus khedaensis from the Lameta Formation, district Kheda, western India. In: Perez-Moreno, B.P., Holtz, A., Sanz, J.L., Mortella, J. (eds.), Aspects of Theropod Biololgy. GAIA $15,379-387$

Loyal, R.S., Khosla, A., Sahni, A., 1996. Gondwanan dinosaurs of India: affinities and palaeobiogeography. Memoirs of the Queensland Museum, Brisbane, Australia, 39 (3), 627 - 638.

Lydekker, R., 1890. Note on certain vertebrae remains from Nagpur District. Records of Geological Survey of India 23, 20-24.

Lydekker, R., 1879. Indian pre-Tertiary vertebrate: Fossils reptilia and batrachia. Memoir of Geological Survey of India, Paleontological Division 4, 1-36.

Lydekker, R., 1877. Note of new and other vertebrate from Indian Tertiary and secondary rocks. Records of Geological Survey of India 10, 38-41.

Mankar, R.S., Srivastava, A.K., 2015. Salbardi-Belkher inland basin: a new site of Lameta sedimentation at the border of districts Amravati, Maharashtra and Betul, Madhya Pradesh, Central India. Current Science 109 (07), 1337-1344

Mately, G.E., 1921. Stratigraphy, fossils and geological relationship of the Lameta beds of Jabalpur, M. P. Journal of the Geological Society of India 53, 142-169.

Mathur, U.B., Pant, S.C., 1986. Sauropd dinosaur humeri from Lameta Group (Upper Cretaceous- ?Palaeocene) of Kheda District, Gujrat. Journal of the Palaeontological Society of India 31, 22-25.

Mohabey, D.M., Samant, B., 2013. Deccan continental flood basalt eruption terminated Indian dinosaurs before the Cretaceous-Paleogene boundary. Journal of the Geological Society of India, Special Publication, 1, 260-267.

Mohabey, D.M., Samant, B., 2009. Palynoflora from Deccan volcano-sedimentary sequence (Cretaceous-Palaeogene transition) of central India: implications for spatio-temporal correlation. Journal of Biosciences 34, 811-823.

Mohabey, D.M., Samant, B., 2005. Lacustrine facies association of a Maastrichtian lake (Lameta Formation) from Deccan volcanic terrain, Central India: implications to depositional history, sediment cyclicity and climates. Gondwana Geological Magazine, Special Volume, 8, 37-52.

Mohabey, D.M., 2001. Dinosaurs eggs and dung (fecal mass) from the Late Cretaceous of Central India, dietary implications. Geological Survey India, Special Publication, 64, 605-615.
Mohabey, D.M., 2000. Understanding community structure, nesting and extinction of Upper Cretaceous (Maastrichtian) Indian dinosaurs: evidences from eggs and nests. Gondwana Geological Magazine 15 (2), 1-23.

Mohabey, D.M., 1998. Systematics of Indian Upper Cretaceous dinosaur and chelonian eggshells. Journal of the Vertebrate Paleontology 18 (2), 384-362.

Mohabey, D.M., 1996 a. Depositional environments of Lameta Formation (Late Cretaceous) of Nand-Dongargaon inland basin, Maharashtra: the fossil and lithological evidences. Memoir, Journal of the Geological Society of India 37, 363386.

Mohabey, D.M., 1996 b. A new oospecies Megaloolithus matleyi from the Lameta Formation (Upper Cretaceous) of Chandrapur district, Maharashtra, and general remarks on the palaeoenvironment and nesting behavior of dinosaurs. Cretaceous Research 17, 183-196. https://doi.org/ $10.1006 /$ cres.1996.0014

Mohabey, D.M., Udhoji, S.G., Verma, K.K., 1993. Palaeontological and sedimentological observations of nonmarine Lameta Formation (Upper Cretaceous) of Maharashtra, India: their palaeoecological and palaeoenvironmental significance. Palaeogeoraphy, Palaeoclimatology, Palaeoecology 105 (1-2), 83-94. https://doi.org/10.1016/0031-0182(93)90108-U

Mohabey, D.M., Udhoji, S.G., 1993. Palaeoenvironmental interpretation of Lameta Formation (Late Cretaceous) of Nand area, Nagpur district, Maharashtra. Gondwana Geological Magazine 4-5, 13-22.

Mohabey, D.M., 1991. Palaeontological Studies of the Lameta Formation with Special Reference to Dinosaurian Eggs from Kheda and Panchmahal Districts of Gujarat, India. Unpublished Ph. D. thesis, Nagpur University, Nagpur, 124 p.

Mohabey, D.M., 1990. Dinosaur eggs from Lameta Formation of Western and Central India: their occurrence and nesting behavior. In: Sahni, A. and Jolly, A. (eds.), Cretaceous Event Stratigraphy and Correlation of the Indian Nonmarine Strata, Panjab University, Chandigarh, pp. 18-21

Mohabey, D.M., 1987. Juvenile sauropod dinosaur from Upper Cretaceous Lameta Formation of Panchmahals district, Gujarat, India. Journal of the Geological Society of India 30 (3), 210-216.

Mohabey, D.M., 1984. Study of dinosaurian eggs from infratrappean limestone in Kheda district, Gujarat. Journal of the Geological Society of India 25(6), 329-337.

Mohabey, D.M., 1983. Note on occurrence of dinosaurian fossil eggs from infratrappean limestone in Kheda District, Gujarat. Current Science 52 (24), 1194.

Pascoe, E.H., 1964. Manual of Geology of India and Burma, Vol. III, thirded., Government of India Publication, New Delhi.

Saha, O., Shukla, U.K., Rani, R., 2010. Trace fossils from the Late Cretaceous Lameta Formation, Jabalpur area, Madhya Pradesh: paleoenvironmental implications. Journal of the Geological Society of India 76 (6), 607-620.

Sahni, A., Tandon, S.K., Jolly, A., Bajpai, S., Sood, A., Srinivasan, S., 1994. Upper Cretaceous dinosaur eggs and nesting sites from the Deccan-volcano sedimentary province of peninsular India. In: Carpenter, K., Hirsch, K.F., 
Horner, J.R. (eds.), Dinosaur Eggs and Babies, Cambridge University Press, New York, pp. 204-226.

Sahni, A., 1993. Eggshell ultrastructure of Late Cretaceous Indian dinosaurs. In: Kobayashi, I., Mutvei, H. and Sahni, A., (eds.), Proceedings symposium, structure, formation and evolution of fossil hard tissues. Tokyo, Japan: Tokai University Press, pp. 187-194.

Sarkar, A., Bhattacharya, S.K., Mohabey, D.M., 1991. Stable isotope analysis of dinosaur eggshells: palaeonvironmental implication. Geology 19, 1068-1071.

Shukla, U.K., Srivastava, R., 2008. Lizard eggs from Upper Cretaceous Lameta Formation of Jabalpur, Central India, with interpretation of depositional environments of the nest-bearing horizon. Cretaceous Research 29 (4), 674-686.

Singh, V., Tandon, S.K., 2004. Facies associations and sedimentary petrological characteristics of Lameta sequences of the Dongargaon area, Central India. Journal of the Geological Society of India 63, 39-50.

Singh, I.B., Sherekar, S., Agrawal, C., 1983. Palaeoenvironment and stratigraphic position of Green Sandstone (Lameta: Late Cretaceous) Jabalpur area. Journal of the Geological Society of India 24, 412-420.

Singh, I.B., 1981. Palaeoenvironment and palaeogeography of Lameta Group sediments (Late Cretaceous) in Jabalpur area, India. Journal of the Palaeontological Society of India,26, 38-46.

Singh, I.B., Srivastava, H.K., 1981. Lithostratigraphy of Bagh Beds and its correlations with Lameta beds. Journal of the Palaeontological Society of India 26, 77-85.

Srivastava, A.K., Kandwal, N.K, Humane, S.K., Humane, S.S., Kundal, P., Khare, N., 2018. Record of calcareous algae from the Lameta Formation: a new insight for possible sea incursion during the Maastrichtian time. Arabian Journal of Geosciences 11-14, 1-15. https://doi.org/10.1007/s12517017-3333-1.

Srivastava, A.K., Kandwal, N.K., 2016. Lithological setting and granulometry of the Lameta sediments from new locality exposed at Pandhari village, district Betul, Madhya Pradesh. Journal of the Indian Association of Sedimentologist 33 (1, 2), 1-11.

Srivastava, A.K., Mankar, R.S., 2015 a. Lithofacies architecture and depositional environment of Late Cretaceous Lameta sediments, Central India. Arabian Journal of Geosciences 8, 207-226. https://doi.org/10.1007/s12517-013-1192-y

Srivastava, A.K., Mankar, R.S., 2015 b. Megaloolithus dinosaur nest from Lameta succession of Salbardi area, districts Amravati, Maharashtra and Betul, Madhya Pradesh, Journal of the Geological Society of India 85, 457-462.

Srivastava, R., Patnaik, R., Shukla, U.K., Sahni, A. 2015. Crocodilian nest in a Late Cretaceous sauropod hatchery from the type Lameta Ghat locality, Jabalpur, India. PloS ONE 10(12): e0144369. https://doi.org/10.1371/journal.pone. 0144369.

Srivastava, A.K., Mankar, R.S., 2013. A dinosaurian ulna from a new locality of Lameta succession, Salbardi area, districts Amravati, Maharashtra and Betul, Madhya Pradesh, Current Science 105 (7), 901-902.
REVIEW PAPER

Srivastava, A.K., Mankar, R.S., 2012 a. Record of trace fossils from the Lameta successions of Salbardi and Belkher area, district Amravati, Maharashtra and their palaeoecological and palaeoenvironmental significance. Arabian Journal of Geosciences 5, 1003-1009.

Srivastava, A.K., Mankar, R.S., 2012 b. Field observations, petrography and diagenesis of Lameta sediments exposed at the northern boundary of district Amravati, Maharashtra. Gondwana Geological Magazine 27(1), 31-42.

Srivastava, A.K., Mankar, R.S., 2010. Sedimentological studies and trace fossils of the Lameta successions of Bairam, Belkher and Salbardi area, district Amravati, Maharashtra. Gondwana Geological Magazine 12, 209-224.

Srivastava, A.K., Mankar, R.S., 2008. Lithofacies, depositional environment and age of upper Gondwana succession of Salbardi area, Amravati district, Maharashtra and Betul, Madhya Pradesh. Journal of the Geological Society of India 72, 190-198.

Srivastava, A.K., Banubakode, P.D., Kale, V.M., Patil, G.V., 1999. Lower Cretaceous plant fossils from Upper Gondwana succession of Bairam-Belkher area, district Beitul, Mahdya Pradesh and district Amravati, Maharashtra and its significance in stratigraphy. Palaeobotanist 48, 39-38.

Srivastava, A.K., Banubakode, P.D., Kale, V.M., Patil, G.V., 1995. Record of Upper Gondwana flora from BairamBelkher area of district Amravati, Maharashtra and district Betul, Madhya Pradesh. Current Science 69 (5), 397-400.

Srivastava, S., Mohabey, D.M., Sahni, A., Pant, S.C., 1986. Upper Cretaceous dinosaur egg clutches from Kheda district, Gujarat, India: their distribution, shell ultrastructure and palaeoecology. Palaeontographica A 193, 219-233.

Tandon, S.K., Andrews, J.E., 2001. Lithofacies associations and stable isotopes of palustrine and calcrete carbonates: examples from an India Maastrichtian regolith. Sedimentology, 48, 339-355. https://doi.org/10.1046/ j.1365-3091.2001.00367.x

Tandon, S.K., Andrews, J.E., Sood, A., Mittal, S., 1998. Shrinkage and sediments supply of multiple calcrete profile development: a case study from the Maastrichtian of Central India. Sedimentary Geology 119, 25-45. https://doi.org/10.1016/S0037-0738(98)00054-2

Tandon, S.K., Andrews, J.E., Dennis, P.F., 1995. Palaeoenvironments of dinosaur bearing Lameta beds (Maastrichtian), Narmada valley, Central India. Palaeogeoraphy, Palaeoclimatology, Palaeoecology 117, 153-184. https://doi.org/10.1016/0031-0182(94)00128-U

Tandon, S.K., Verma, V.K., Jhingran, V., Sood, A., Kumar, S., Kohli, R.P., Mittal, S., 1990. The Lameta Beds of Jabalpur, Central India: deposits of fluvial and pedogenically modified semi-arid pre-palustrine flat systems. Sahni, A., Jolly, A. (eds.), Cretaceous Event Stratigraphy and the Correlation of the Indian Non-marine Strata. Contribution, Symposiumcum Workshop, ICGP-216 and 245, Chandigarh, pp. 75-77.

Vianey-Liaud, M., Khosla, A., Garcia, G. 2003. Relationships between European and Indian dinosaur eggs and eggshells of the oofamily Megaloolithidae. Journal of Vertebrate 
Paleontology 23, 575-585. https://doi.org/10.1671/02724634(2003)023[0575:RBEAID]2.0.CO;2

Vianey-Liaud M., Jain, S.L., Sahni A., 1987. Dinosaur eggshells (Saurischia) from the Late Cretaceous Intertrappean and Lameta Formations (Deccan, India). Journal of Vertebrate Paleontology 7, 408-424.

Wilson, J.A., Upchurch, P., 2003. A revision of Titanosaurus lydekeer (Dinosauria-Sauropoda), the first dinosaur genus
REVIEW PAPER with Gondwana distribution. Journal of Systematic Palaeontology 1(3), 125-160.

Wilson, J.A., Sereno, Srivastava, S., Batt, D.K., Khosla, A., Sahni, A., 2003. A new Abelisaurid (Dinosauria-Sauropoda) from the Lameta Formation (Cretaceous: Maastrichtian) of India. Contributions from the Museum of Palaeontology, University of Michigan, 31(1), 1-42. 